\title{
Despre tratamentul neologismelor în DELR. Corijări și completări etimologice
}

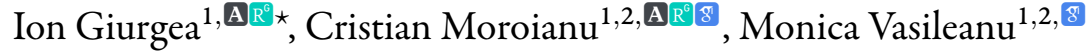 \\ ${ }^{1}$ Institutul de Lingvistică „Iorgu Iordan - Al. Rosetti”, Calea 13 Septembrie 13, 050711 București, România \\ ${ }^{2}$ Facultatea de Litere, Universitatea din București, Str. Edgar Quinet 5-7, Sector 1, 010017 București, România
}

\section{Despre articol}

Istoric:

Primit 2 martie 2020

Acceptat 15 martie 2020

Publicat 10 iunie 2020

Cuvinte-cheie:

etimologie

neologism

împrumut

mijloace interne

\begin{abstract}
Rezumat
Autorii, redactori și revizori ai DELR, propun o discuție asupra tratării originii neologismelor în dicționarele noastre academice, cu referire la literele $A-D$ (parțial) și dau exemple de rezolvări etimologice noi, corectînd și completînd soluțiile propuse în DEX și în DLR. Cu această ocazie, vor fi actualizate cîteva dintre criteriile obținerii unei etimologii științifice și vor fi reinterpretate concepte precum etimologia multiplă sau etimologia mixtă, în variatele lor forme de manifestare. Sînt discutate soluții etimologice pentru 132 de cuvinte, organizate în funcție de criteriul predominant folosit în stabilirea etimologiei.
\end{abstract}

\section{Introducere}

Prezentul articol propune o serie de corijări și completări etimologice la tratamentul neologismelor din dicționarele noastre academice mai vechi sau mai noi, pe baza primelor trei volume ale DELR $(2011,2015$ și 2018) și a lucrărilor în curs la volumul al patrulea și la revizuirea primului volum ${ }^{1}$.

Etimologia cuvintelor unei limbi este una dintre cele mai importante componente ale respectivei limbi din următoarele motive: 1) pune în evidență contactele—atît cele populare, cît și, mai ales, cele culturale-pe care vorbitorii unei limbi le-au avut (de la constituirea ei) și le au în continuare cu limbile cu care societatea din care aceștia fac parte s-a aflat în contact (geografic, cultural sau civilizațional); 2) conduce la realizarea unor statistici relevante privitoare la numărul și calitatea cuvintelor care constituie vocabularul unei limbi; 3) relevă tendințele pe care le presupune îmbogățirea și diversificarea lexicală, în legătură directă cu integrarea respectivei limbi în circuitul relațiilor cu celelalte culturi și civilizații.

După cum se știe, vocabularul limbii noastre cunoaște o mare diversitate etimologică, româna fiind influenţată, pe parcursul istoriei sale și în directă dependență de poziția sa geografică, în mod substanțial, de limbi precum vechea slavă, bulgara, sîrba, turca, maghiara, germana, ucraineana, pe de o parte, rezultat al contactului direct cu populațiile vecine și al conviețuirii intra- și interetnice; pe de altă parte, a cunoscut multiple influențe culturale, începînd cu slavona în perioada veche și continuînd, succesiv, cu latina cultă, neogreaca, franceza, (din nou) germana, italiana, rusa și engleza, dintre care unele constituie, în continuare, surse substanţiale de împrumuturi. Unele dintre acestea, precum neogreaca și rusa, fie și-au încetat, fie şi-au diminuat considerabil calitatea de limbi furnizoare de cuvinte, rolul lor „istoric” în organizarea societăţii românești fiind dependent de perioade și de condiţii sociopolitice depășite. Altele, precum latina cultă, italiana și, mai nou, spaniola contribuie și astăzi, în măsură diferită, la dezvoltarea lexicului: latina a rămas o sursă importantă pentru împrumutarea unor termeni savanți, în vreme ce din italiană și din spaniolă pătrund cuvinte care denumesc „realia” specifice celor două culturi. În sfîrșit, engleza și-a intensificat

^Adrese de corespondență: giurgeaion@yahoo.com (IG), cristian_moroianu@hotmail.com (CM),monica.vasileanu @gmail.com (MV).

${ }^{1}$ În prezent, volumul I al DELR se află într-o fază de completare și de actualizare a conținutului, conform ultimelor norme intrate în vigoare odată cu cel mai recent volum publicat (vol. II, partea a II-a, 2018, v. Bibliografia). 
Ion Giurgea, Cristian Moroianu \& Monica Vasileanu

aportul la îmbogățirea vocabularului într-un context socio-economic care amintește, mutatis mutandis, de influența franceză dominantă din secolul al XIX-lea, dar care se particularizează prin caracterul său globalizant.

Unul dintre aspectele importante ale activităţii lexicografice, în mod particular, a celei academice este propunerea de soluții etimologice cît mai aproape de realitatea creării sau pătrunderii în limbă a unităţilor lexicale, cu alte cuvinte care să corespundă cît mai multor criterii de stabilire a unei etimologii științifice (Sala, 1999, p. 23-32). În sinteză, o sursă lexicală externă (unică sau multiplă) poate fi considerată etimon ${ }^{2}$ al unui cuvint românesc dacă:

a) există o corespondență vizibilă sau motivabilă la nivel formal (fonetic, morfematic și morfologic) și la nivel semantic, ținîndu-se cont de evoluția în timp, pe terenul limbii-gazdă, a respectivului cuvînt (criteriile formal și semantic);

b) etimonul extern presupus este atestat în limba de origine într-o perioadă anterioară prezenței lui în română (criteriul cronologic $)^{3}$;

c) etimonul extern are $o$ anumită vechime și circulație în limba de origine, cu care se presupune că româna s-ar fi aflat în contact în perioada împrumutului (criteriul frecvenței $)^{4}$;

d) etimonul direct aparţine, în cazul unui împrumut popular, unei limbi aflate în vecinătate geografică cu zona în care a pătruns respectivul cuvînt (criteriul geografic);

e) etimonul extern a aparținut sau aparține, în diverse etape de evoluție a societăţii, unui nivel de limbă care a reflectat sau reflectă o puternică influență externă (criteriul istoric și cultural), unică sau multiplă, confirmată de orizontul cultural și orientarea lingvistică a autorilor la care au fost atestate pentru prima dată împrumuturile respective.

În cazul unei soluții interne, trebuie respectate cel puțin:

a) criteriul formal, care are în vedere, în cazul cuvintelor analizabile, explicarea construcției morfematice, completat de

b) criteriul derivațional, care presupune compatibilitatea dintre categoria lexico-gramaticală a bazei lexicale cu un anumit afix derivativ ${ }^{5}$,

c) criteriul etimologiei afixelor, care arată că derivarea cu un afix originar din altă limbă decît baza nu este posibilă decît la nivel intern și

d) criteriul semantic (compoziționalitatea sensului).

În sfirșit, în cazul împrumuturilor culturale, mai vechi sau mai noi, trebuie avută în vedere posibilitatea construirii lor din material lingvistic autohton după unul sau mai multe modele externe structural analizabile, așadar calcul lexical (în principal, cel de structură morfematică) și cel lexico-gramatical. Criteriile esențiale în considerarea calcului ca soluție etimologică sînt cel cronologic și cel istorico-cultural.

O situație particulară este reprezentată de etimologia multiplă externă și de cea mixtă. Etimologia multiplă externă presupune, în mod obiectiv, împrumutarea unui cuvînt din două sau mai multe surse externe, simultan sau succesiv, soluție favorizată, printre altele, de caracterul internațional al cuvîntului,

\footnotetext{
${ }^{2}$ Prin convenție, în acest context înțelegem prin etimon atît o sursă externă unică, cît și una multiplă.

${ }^{3}$ În acest caz, criteriul cronologic este completat de cel semantic și de cel cultural. Spre exemplu, verbul a decădea nu este o creație internă, ci este un împrumut din it. decadere și din fr. déchoir, românizat după cădea; descrește nu se explică exclusiv din des- + crește, ci trebuie raportat la un model extern (calc după fr. décroître) etc.

${ }^{4}$ Dacă însă cuvîntul respectiv aparține unui limbaj cu un grad ridicat de specializare, frecvența lui în limba de origine nu este relevantă, el avînd o circulație restrînsă atît în limba din care provine, cît și în cea care îl împrumută. În această situație, o mai mare relevanță au criteriul cronologic, respectiv anterioritatea atestării lui într-o altă limbă, și cel cultural. Spre exemplu, un cuvînt cu circulație internațională și avînd structură în întregime analizabilă poate fi considerat, în funcție de momentul în care pătrunde în română, inclusiv creație internă dacă nu există suficiente argumente pentru considerarea lui exclusivă ca împrumut (nu este un concept specific unei alte limbi, nu are un autor cunoscut care să îl impună).

${ }^{5}$ Spre exemplu, ca regulă generală, prefixul negativ ne- nu se ataşează direct infinitivului scurt, sufixul -bil este atașat exclusiv verbelor, sufixul -os este exclusiv postsubstantival etc. Aparentele excepții de la aceste reguli trebuie explicate prin raportare la fenomene analogice, spre exemplu, derivarea prin substituție, pentru care vezi Moroianu (2008, p. 194-206; 2009, p. 281-294).
} 
de similitudinea formală și semantică a etimoanelor externe directe (care, la rîndul lor, au aceeaşi origine, directă sau îndepărtată), de influențele externe multiple care caracterizează o anumită epocă, o anumită regiune sau profilul multilingvistic al unui autor ${ }^{6}$. Etimologia multiplă mixtă ia în considerare posibilitatea ca un anumit cuvînt, aparținînd epocii de maturitate structurală a limbii române moderne și avînd o formă în întregime analizabilă, să poată fi atît împrumutat, cît și format pe cale internă, în mod independent de prezența sa în alte limbi cu care româna să aibă contacte. Spre exemplu, dacă nu există contraargumente de ordin cronologic, semantic sau al poziției în limbă, deverbalele neologice cu prefixul re- pot fi considerate, în egală măsură, creații interne sau împrumuturi analizabile, de regulă din franceză (vezi reabona, atestat la sfirșitul secolului al XIX-lea, reangaja, atestat la începutul secolului trecut, ca și recombina, de altfel), adjectivele sau substantivele relativ recente cu prefixele anti- sau pro- permit, de asemenea, o dublă explicație: derivate interne sau împrumuturi analizabile (vezi antiacademic, atestat începînd cu anii ' 60 ai secolului $\mathrm{XX}$ ), numeroase verbe neologice pot fi derivate directe din adjective sau din substantive atît în alte limbi (înrudite genetic sau cultural), de unde să le fi împrumutat ca atare, cît și pe teren românesc (vezi anagrama vb. „a face o anagramă”, derivat intern postsubstantival sau împrumut din fr. anagrammer, ancora vb. „a fixa o navă cu ajutorul unei ancore", derivat intern postsubstantival sau împrumut din it. ancorare, absenta „a fi absent”, absolutiza „a atribui în mod exagerat unui fapt sau unei idei o valoare absolută”, accidenta „a provoca un accident”, clica ,a selecta cu ajutorul unui clic" etc.). Adjectivele recente în -bil au, de multe ori, etimologie multiplă mixtă (vezi acordabil, $-\breve{a}$,care poate fi acordat”, ameliorabil, $-\breve{a}$ "care se poate ameliora”, clasabil, $-\breve{a}$ „care se poate clasa”, conectabil, $-\breve{a}$ „care se poate conecta”) etc. Același fenomen privește și adjectivele recente provenite din toponime (spre exemplu, anatolian adj. „din Anatolia”, din fr. anatolien sau derivat etnic din Anatolia, anexionism s.n. "politică de anexiune”, derivat intern sau împrumut din fr. annexionnisme etc.). În asemenea situații, chiar dacă se poate proba cu argumente o sursă externă, ea nu poate și nu trebuie să fie considerată exclusivă, respectivele cuvinte putînd fi create, în paralel, și prin mijloace interne. Nu trebuie desconsiderată nici analogia, mai ales atunci cînd o potențială sursă externă presupune diverse probleme (spre exemplu, adverbul livresc abruptamente este explicabil, pe de o parte, prin fr. abruptement, adaptat clasei adverbelor în -(a)mente, majoritatea împrumutate din italiană, și, pe de altă parte, direct din baza românească abrupt, după modelul lui certamente, finalmente, totalmente etc.; varianta amicabil a adj. amiabil se poate explica fie ca împrumut din lat. amicabilis, fie ca „românizare” a fr. amiable, după modelul lui amic; varianta complecta a verbului completa este fie o derivare directă din baza complect (= complet), fie un împrumut din rus. komplektovat' etc.). Tot într-o manieră dublă se pot explica și bioclimatolog s.m. „specialist în bioclimatologie”, împrumut din fr. bioclimatologue sau derivat regresiv din bioclimatologie, climatiza vb. „a asigura temperatura și umiditatea optime într-o încăpere", împrumut din fr. climatiser sau refăcut din climatizare (care este atestat cu trei decenii înaintea verbului și care are o frecvență mult mai mare decît a acestuia), clip s.n. „succesiune de secvențe video, realizată pentru promovarea unei persoane sau a unui produs comercial", trunchiere internă din compusul videoclip sau împrumut din engl. clip etc. .

În noua concepție, asumată de DELR începînd cu partea a doua a celui de al doilea volum (apărut la Editura Academiei în 2018), este valorificat, complementar datelor lexicologice și lexicografice extrase critic din dicționarele de referință (PEW, CDDE, DA/DLR, CADE, SDLR, CDER, DÎLR etc.), din lucrări fundamentale dedicate principalelor influențe lexicale și din principalele reviste lingvistice, un bogat corpus electronic de texte din cele mai variate domenii și extins pe întreaga istorie a limbii române ${ }^{8}$. Avantajele

\footnotetext{
${ }^{6}$ Etimologie multiplă externă pot avea, în egală măsură, și variantele etimologice ale împrumuturilor: spre exemplu, var. chiarificațiune a s.f. clarificație se poate explica fie ca un împrumut din it. chiarificazione, fie prin românizarea fr. clarification.

${ }^{7}$ Vezi Hristea (1973a, p. 3-15). Există inclusiv posibilitatea ca un cuvînt să poată pătrunde din două surse externe analizabile (deci să aibă o etimologie multiplă externă) și să fie construit, cu aceleaşi sensuri sau cu sensuri diferite, prin mijloace derivative interne (caz în care ne aflăm în faţa unei etimologii mixte). Spre exemplu, aristocratism s.n. „atitudine aristocratică”, atestat la jumătatea secolului al XIX-lea (1859, Bălășescu, D. R.-Fr.), se explică atît din fr. aristocratisme, rus. aristokratizm, cît şi direct din aristocratic (cu substit. sufixului).

${ }^{8}$ Acest corpus de texte a fost alcătuit în cadrul Departamentului de Lexicografie al Institutului de Lingvistică „Iorgu Iordan - Al. Rosetti”.
} 
Ion Giurgea, Cristian Moroianu \& Monica Vasileanu

unei cercetări a textelor pe baza resurselor electronice sînt indiscutabile: aceasta permite atît verificarea surselor cunoscute, pentru identificarea eventualelor variante primare, de regulă etimologice, cît și datări anterioare, uneori cu decenii sau chiar secole înainte. De asemenea, se pot verifica mai relevant criteriile semantic și funcțional (respectiv în ce măsură un etimon extern propus apare în limba de origine înaintea corespondentului românesc și care îi era gradul de utilizare) și se poate urmări istoria referentului (concept sau obiect), cu tot ceea ce presupune ea (criterii culturale, date auctoriale, apartenența la un anumit domeniu etc.). Tot acest instrumentar electronic permite, prin comparație cu resursele avute la dispoziție de dicționarele noastre mai vechi, o cercetare lexicologică mai aprofundată a cuvintelor și o construcție lexicografică mai coerentă și mai bine argumentată din toate punctele de vedere.

În cele ce urmează, prezentăm o serie de corectări și completări etimologice aduse în volumele deja publicate sau aflate în lucru ale DELR. Deoarece, în cazul neologismelor, sursele lexicografice existente propun, de cele mai multe ori, etimoane ${ }^{9}$, soluțiile noi propuse de DELR se raportează, în general, la soluții deja existente, în respingerea sau corectarea cărora au fost folosite unul sau mai multe dintre criteriile expuse mai sus. Aceasta a permis organizarea materialului în funcție de criteriile menționate: secțiunile 2-6 tratează criteriile formal, respectiv semantic, cronologic, al frecvenței, al istoriei conceptului/referentului, iar secțiunea 7 are în vedere cazurile, mult mai puține la număr, în care DELR a propus etimologii pentru termenii neologici notați cu „etimologie necunoscută” în lucrările precedente. În unele cazuri am menționat sursele primelor atestări ale cuvintelor, folosind sigle care sînt explicate în bibliografia DELR vol. II, partea a II-a.

\section{Criteriul formal}

Criteriul formal (sau fonetic, Sala, 1999, p. 23-25) este cel mai evident argument în stabilirea etimologiei unui cuvînt—și adeseori poate fi înșelător, după cum se va vedea mai jos (în secțiunea 3). Modificările formale (fonetice și morfologice) depind de vechimea cuvîntului (moștenit vs împrumut) și de calea de pătrundere (populară vs cultă / orală vs scrisă). În cazul neologismelor, diferențele formale dintre etimon și cuvîntul-rezultat nu sînt majore și țin mai degrabă de adaptarea morfologică, precum și de adaptarea fonemelor nespecifice limbii române la sistemul fonetic românesc. Cu toate acestea, au existat cîteva situaţii în care DELR a propus etimoane noi pentru neologisme, cu argumente care țin mai degrabă de criteriul formal.

\subsection{Etimoane directe cu o formă mai apropiată de a cuvîntului românesc}

Pentru împrumuturile (relativ) recente, s-a întîmplat rareori ca dicționarele academice de referință să nu identifice un etimon direct precis, întrucît ele provin din limbi bine atestate și prezintă modificări fonetice minore. Totuși, în anumite situații, s-a propus raportarea la un etimon străin-de obicei valabil ca etimon îndepărtat-prin indicații mai puțin precise precum „cf.” sau „după”, fără a se identifica un etimon direct. Sporirea bazei documentare a DELR, în special prin accesul la diferite resurse electronice recente, a permis identificarea unui etimon direct care are o formă mai apropiată de cuvintul românesc. De exemplu, pentru acipenserid s.m. „sturion”, DEX a propus raportarea la lat. acipenser (prin indicaţia „cf.”), care într-adevăr stă la baza cuvîntului românesc, însă prin derivatul lat. savant Acipenserida (< acipenser / acupenser / aquipenser „sturion”) și prin engl. acipenserid. La fel, rom. cașera „a aplica un strat de material peste o hîrtie pentru a-i da un aspect mai frumos" este raportat în DEX la fr. cacher; acesta este, de fapt, etimonul îndepărtat, intermediarul fiind germ. kaschieren, care poate explica mai bine forma cuvîntului românesc. Verbul cașura, cu același sens, provine din caşera, care a fost apropiat, prin etimologie populară, de hașura. DEX, care înregistrează infinitivul lung caşurare, îl explică prin cașa s.f. „stofă de lînă cu tușeul moale, vopsită în culori deschise", soluție inadmisibilă atît din motive formale, cît și din motive semantice.

Pentru adj. antum, legătura cu lat. ante a fost sesizată de DEX, lipsind însă veriga de legătură, anume fr. anthume < [post]hume (împrumut din lat. postumus, TLF), cuvînt francez obținut printr-o substituție

\footnotetext{
${ }^{9}$ Cazurile de etimologie necunoscută sînt foarte rare la neologisme.
} 
antonimică (etimonul anthume a fost semnalat deja de $\mathrm{DN}^{3}$ ). În mod similar, adj. caniculat „(bot.; despre un organ) care are șanțuri semicirculare” a fost pus de DEX în legătură cu fr. cannelé, un termen din domeniul arhitecturii („cu caneluri”); pentru cuvîntul românesc am identificat un etimon mai apropiat formal, dar și semantic, fr. canniculé, un cuvînt neînregistrat în dicționarele de referință (TLF, Larousse), dar înregistrat în Nouveau dictionnaire d'histoire naturelle, appliquée aux arts, vol. XXXIV, 1819, disponibil online. Fr. canniculé a fost, probabil, împrumutat din lat. savant canniculatus < canniculus "mic canal, șanțuleț" < canna „trestie; tub, țeavă”, cf. și engl. canniculated. Și etimonul la care îl raportează, cu destulă precauție, DEX, anume fr. cannelé, provine, prin derivări succesive și împrumut, din lat. canna "trestie”.

Substantivul caradriiformă „ordin de păsări comestibile, cu ciocul și picioarele lungi”, pus de DEX în legătură cu termenul francez curent prin care se denumește acest ordin de păsări, charadriidés, trebuie

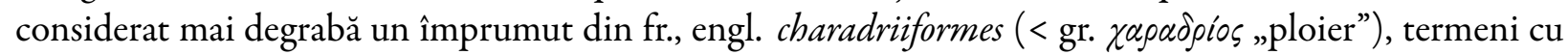
circulație restrînsă, însă acceptați în taxonomiile biologice din cele două limbi. În mod similar, monoclorurat a fost etimologizat în DEX ca fiind format „după fr. monochloré”, ceea ce sugerează o derivare în interiorul limbii române; DELR identifică un etimon direct mai apropiat formal, din aceeași familie cu modelul sugerat de DEX, anume fr. monochloruré, cuvint neînregistrat în TLF sau Larousse, dar atestat în cărți din secolul al XIX-lea (de exemplu, Encyclographie dessciencesmédicales, Établissement Encyclographique, 1840, disponibil online).

În cazul substantivului cașa „un fel de stofă moale de lînă”, etimonul propus de DEX nu are nicio legătură etimologică cu cel identificat de noi: DEX trimite, prin „cf.”, la germ. kaschieren „a ascunde, a camufla”, verb care se folosește și în industria textilă cu sensul „a uni două țesături cu un adeziv”. Însă caşa se explică direct prin fr. kasha, marcă înregistrată, cuvînt format pe baza lui cachemire, Kashmir „caşmir”, soluție care ține cont, pe lîngă criteriul formal, și de argumente istorice și semantice.

Uneori, etimonul are în limba-sursă mai multe variante. Astfel, pentru ciclamă, numele unei flori, DEX propune ca etimon direct it. ciclamino, cf. fr. cyclamen. În italiană, floarea se mai numește și ciclamo sau ciclame, formă mai veche care a circulat și la începutul secolului al XX-lea, cînd este atestat împrumutul, şi considerată etimon direct în DELR. De asemenea, DELR ia în considerare și fr. cyclame, o denumire mai veche și mai rară a aceleiaşi flori, cu un reflex vizibil în rom. siclamă, precum și germ. Zyklame, pentru varianta rom. țiclamă.

Selectarea unui etimon pe baza criteriului formal trebuie să țină cont și de pronunția acestuia. Astfel, rom. curry, pronunțat ['kıri, 'k3ri], nu poate proveni din fr. curry (care are și accent oxiton), după cum propune DEX, ci reprezintă un împrumut din engl. curry (< tamil kari „sos condimentat”), după propunerea $\mathrm{DCR}^{3}$.

\subsection{Identitatea categoriei lexico-gramaticale}

În general, etimonul și cuvintul împrumutat trebuie să facă parte din aceeași clasă lexico-gramaticală. Este de presupus că un adjectiv neologic din română provine dintr-un adjectiv francez, de exemplu.

Astfel, pentru adj. fitocenotic, DEX propune un etimon substantival, fr. phytocénose, care nu corespunde nici fonetic, nici gramatical cuvîntului românesc. DELR propune împrumutul din adjectivul fr. phytocénotique (pentru care vezi și MDA, s.v.), dar nu respinge nici posibilitatea unei derivări interne, prin substituție de sufix, din fitocenoză, explicație propusă, anterior, în $\mathrm{DN}^{3}$. Aceeași situație se întîlnește și în cazul adjectivului topoclimatologic, explicabil fie ca împrumut din fr. topoclimatologique (adj.), fie ca derivat intern, prin substituție de sufix, de la topoclimatologie (cele două soluții oferite de DELR), în niciun caz ca împrumut direct din fr. topoclimatologie, cum apare în DEX. În aceste cazuri, este posibil să fie vorba de greșeli de natură redacțională.

\subsection{Etimoane cu forme diferite in limba de origine}

Uneori, etimoanele propuse în dicționarele academice de referință nu au forma respectivă în limba de origine. În asemenea situații, în DELR au fost corectate formele etimoanelor sau identificate alte etimoane în alte limbi, mai apropiate formal de neologismele românești. 
Ion Giurgea, Cristian Moroianu \& Monica Vasileanu

De cele mai multe ori, diferențele sînt minore și cel puțin unele ar putea reprezenta erori editoriale. De exemplu, pentru chernăr s.n. „punctator; vîrf de centrare la o mașină-unealtă”, DEX propune germ. Kerner, însă forma corectă a cuvîntului este Körner. Pentru colon s.m. „unitate monetară în Costa Rica și El Salvador", etimonul propus în DEX este sp. colono, de fapt colón (denumire monetară în cinstea lui Cristofor Columb, al cărui nume în spaniolă este Cristóbal Colón). De asemenea, pentru originea cuvîntului comanș, DEX propune ca etimon fr. commanci, corectă fiind însă forma Comanche, cuvînt provenit, probabil prin intermediarul engl. Comanche, din sp. comanche, împrumut dintr-o limbă numică (aparținînd familiei uto-aztece), unde avea sensul primar „străin”. Termenul stomatologic pericimentită s.f. „periodontită” este considerat de DLR împrumut din fr. péricimentite, cuvînt care, de fapt, are în franceză forma péricémentite; forma românească se poate explica prin apropiere de ciment, variantă a lui cement „material folosit în obturaţia provizorie a cariilor și la fixarea protezelor”. Pentru protocarburat adj. „care formează o protocarbură”, DEX și DLR indică originea din fr. protocarburat, însă în franceză este atestată forma protocarburé. O eroare redacțională este de bănuit și în cazul substantivului combo „formație orchestrală de jazz compusă din trei pînă la opt instrumentiști”, pentru care DEX trimite la engl. combinaty (sic!), în vreme ce $\mathrm{DN}^{3}$ identifică etimonul corect, engl. combo, trunchiere din combination "combinație".

O situație mai complicată se întîlnește în cazul cuvîntului chalonă s.f. „substanță produsă de glandele cu secreție internă, care, circulînd prin sînge, are acțiune inhibitoare asupra funcțiunii altor organe”, înregistrat în DEX sub forma chalon, cu pronunțarea recomandată / /alon/, și cu indicația etimologică „cuv. fr.”. În franceză, însă, forma reală este chalone, cu pronunția /kalon/. Cuvîntul românesc are de fapt formele chalonă, halonă, înregistrate de D.med. și confirmate de cîteva texte disponibile online. În realitate, cuvîntul provine din fr. chalone, engl. chalone, acesta din urmă fiind creat de fiziologul britanic Sir Sharpley Schäfer, în 1913, pe baza gr. $\chi \alpha \lambda \tilde{\alpha} \nu$ „a lăsa moale, a lăsa să cadă, a da drumul”, cu finala după hormone „hormon”, cf. TLF și Keppel Hesselink (2015).

În alte situații, DELR a identificat etimoane în alte limbi decît cele propuse de dicționarele de referință. De exemplu, pentru aduct „amestec cristalin în care o substanță este înglobată în rețeaua cristalină a altei substanțe”, DEX indică un etimon fr. adducte ${ }^{10}$, însă cuvîntul francez are forma adduit. De aceea, DELR a propus germ. Addukt (< Add[itionpro]dukt < Addition "adăugare, adiție” + Produkt "produs” $<$ lat. productum, part. perf. al vb. producere „a produce”) și engl. adduct. Similar, pentru adjectivul circumvolut, DEX propune un fr. circonvolut; adjectivul francez are însă forma circonvoluté. Din punct de vedere formal, circumvolut este un împrumut din lat. circumuolutus (participiul vb. circumuoluere „a înfăşura, a roti în jurul”), iar evoluția semantică se explică prin raportare la fr. circonvoluté, precum și la abstractul românesc circumvoluție. Un alt exemplu îl constituie fotocopier, un sinonim rar al cuvîntului fotocopiator, pentru care DEX propune un etimon germ. inexistent Photokopier. Cum în germană cuvintul are forma Photokopierer, DELR propune ca etimoane, cu respectarea criteriului formal, fr. photocopieur și engl. photocopier, ambele atestate ca atare și relativ frecvente în limbile de origine.

\subsection{Etimoane valabile doar pentru o variantă}

Uneori, forma propusă în alte dicționare este valabilă doar pentru unele variante. Este cazul cuvîntului calmuc „(persoană) care face parte dintr-o populație mongolică de la nord de Caucaz; (fig., Mold.) mîncăcios, vorace”, pentru care DEX și TDRG ${ }^{2}$ propun etimonul rus. kalmyk. Acest etimon este valabil pentru varianta rom. calmîc, în vreme ce forma calmuc provine din tc. kalmuk și fr. kalmouk (ultimul propus de $\mathrm{DA})$.

\footnotetext{
${ }^{10}$ Preluat fără nicio verificare suplimentară din $\mathrm{DN}^{3}$ și perpetuat aproximativ, din nefericire, inclusiv în MDA s.v., sub forma aducte. De altfel, majoritatea etimologiilor greșite din DEX sînt preluate în MDA.
} 


\subsection{Etimologie internă vs externă $\breve{a}^{11}$}

Criteriul formal oferă argumente pentru a decide dacă un cuvînt este format în interiorul limbii române sau împrumutat. Sufixele, de exemplu, se aplică la anumite tipuri de baze, iar o etimologie care nu respectă aceste restricții nu este verosimilă. Sufixul -tor, care creează nume de agent, se aplică bazelor verbale. Astfel, decimator "persoană însărcinată cu încasarea decimei”, nu poate fi derivat direct din decimă, cum propune DLR. Familia cuvîntului decimă nu cuprinde un verb a decima cu sensul „a încasa decima”, de aceea decimator trebuie considerat împrumut din lat. decimator < decimare „a încasa zeciuiala”. Din aceeași familie face parte și decimație „încasarea decimei”, care nici el nu poate proveni direct din decimă (cum se propune în DLR), ci din lat. decimatio (< decimare „a încasa zeciuiala”). Sufixul neologic -ibil se atașează tot unor baze verbale, de aceea cuvintul conceptibil "care poate fi conceput" nu poate fi derivat din concept $+-i b i l$, după cum propune DEX, ci trebuie explicat prin fr. conceptible.

În egală măsură, criteriul formal poate pleda și în favoarea derivării interne. În cazul adjectivului confundabil "care poate fi confundat", este de respins posibilitatea împrumutului din it. confundibile (sic!), propusă de DEX, din cauza formei sufixului: -abil în loc de -ibil. Forma sufixului indică o derivare internă din verbul a confunda, după cum a propus Seche (1960, p. 57), propunere acceptată de NDU și DELR.

Alteori, chiar dacă nu va permite o decizie categorică între etimologia internă și cea externă, criteriul formal ajută la formularea unor propuneri etimologice mai plauzibile. De exemplu, în cazul adjectivului clientelar „(despre raporturi) bazate pe favoritism; (ist., despre state) aflate sub protecția Romei, în regim de clienți”, derivarea directă din client, propusă în DEX, nu poate fi susținută, întrucît nu există un sufix elar în limba română. În schimb, este posibilă o derivare din clientelă, ipoteză susținută în SDLR și acceptată de DELR, sau un împrumut din fr. clientelaire.

$\mathrm{Nu}$ în ultimul rînd, o modalitate atipică de derivare sau de compunere indică, de multe ori, un calc. În cazul unor componente bine sudate, calcul permite și distingerea exactă a elementelor componente. De exemplu, cuvîntul întrajutorare este explicat în DEX ca un compus din întru + ajutorare, deși este atestat tîrziu, la jumătatea secolului al XX-lea, și înseamnă „ajutorare reciprocă”. Cu aceste argumente de ordin cronologic și semantic, am considerat, în DELR, că ne aflăm în fața unui calc lexical de structură morfematică, construit din între + ajutorare, după modelul fr. entraide.

\section{Criteriul semantic}

\subsection{Semantica termenului în limba-sursă}

În unele cazuri, etimonul propus de alte dicționare academice satisface criteriul formal, dar are, în limba sursă, un sens parțial sau total diferit. Astfel, pentru comper s.m. „prezentator al unui spectacol de divertisment”, DEX propune engl. compeer, însă acest cuvînt are sensurile „persoană egală în rang” și ,însoțitor, tovarăș", provenind din lat. compar (probabil prin fr. med. compar), cu forma adaptată după peer (<v.fr. per < lat. par). Cuvîntul românesc provine de fapt din fr. compère „cumătru” (<lat. compater), care are și sensul „prezentator al unui spectacol de divertisment”.

Cuvîntul corm s.n. „corp al plantelor superioare, format din rădăcină, tulpină și frunze” este dat de DEX ca provenind din fr. corme, care însă înseamnă ,soarbă; organ de rezervă subteran al unor plante avind aspectul unui bulb, dar format dintr-o tijă umflată înconjurată de solzi”. Pentru conceptul corespunzător românului corm, franceza folosește forma cormus, reprezentînd un latinism savant, împrumutat din gr. xopuós „trunchi”. Ca etimon al termenului românesc, se poate presupune it. cormo.

Dacită s.f. „explozibil din grupul dinamitelor de siguranță” nu poate proveni din fr. dacite, care desemnează un tip de rocă, sens cu care a și fost împrumutat în română în forma dacit (cf. și germ. Dazit).

\footnotetext{
${ }^{11}$ Vezi și Hristea (1973b, p. 143-155). Autorul grupează faptele aduse în discuție în trei mari categorii: a) creații interne românești, considerate împrumuturi din alte limbi, b) împrumuturi din diverse limbi interpretate ca formații interne ale limbii române și c) cuvinte cu dublă proveniență (internă și externă).
} 
$\mathrm{Nu}$ am putut identifica un etimon extern pentru dacită, de aceea credem că este vorba de o denumire comercială creată în română, formată cu sufixul -ită caracteristic numelor de explozibile. Încercînd să găsim cum este denumită această substanță în alte limbi (pornind de la formula ei chimică), am întîlnit un termen cu o bază diferită, probabil tot o denumire comercială cu sufixul -it: germ. Fördit.

Pentru verbul delabora, termen militar cu sensul „a demonta instalațiile, mașinile și muniţiile devenite inutilizabile sau periculoase”, $\mathrm{DN}^{2}$ și DEX propun un împrumut din lat. delaborare, dar acest derivat al verbului laborare are sensul „a munci din greu” (prefixul de- nu are sens privativ în acest caz). De altfel, imprumutarea unui termen tehnic al vocabularului militar modern din latină este cu totul neverosimilă. DLR scrie, mai vag, „cf. elabora”. De fapt, cuvîntul, cu sensul din română, se găsește în germană: delaborieren (cu abstractul Delaborierung). El este derivat cu prefixul latin de- cu sens privativ din verbul laborieren „a asambla un dispozitiv explozibil”. Acest sens al verbului laborieren s-a dezvoltat în germană pornind de la sensul „a lucra, a migăli” cu care acest cuvînt a fost împrumutat din latină (laborare < labor, -ōris „muncă”).

În intrarea din DEX culee sînt reunite două omonime, etimonul propus potrivindu-se doar pentru unul dintre ele. Astfel, culee s.f., cu sensurile „stîlp destinat să susţină arcuirea boltei unui edificiu; fiecare dintre cele două masive de zidărie care susțin un pod, situate pe pămînt, la capetele acestuia” provine, într-adevăr, din fr. culée (< cul < lat. cülus „fund”, de unde „capăt de jos, bază”), însă sensul „orificiu sau jgheab prin care se toarnă metal lichid în tipar” nu se poate explica prin fr. culée. Este vorba de fapt de un alt cuvînt, fără vreo înrudire etimologică, provenind din fr. coulée „turnare a unei materii lichide într-o formă” (< couler ,a curge” < lat. cōläre „a strecura, a filtra” < cōlum ,vas de strecurat”).

În cazul adjectivului costier, etimologia corectă este cea propusă de $\mathrm{DN}^{2}$ : fr. côtier, adaptat după coastă. DEX propune însă fr. costière, dar acest cuvînt este doar substantiv, desemnînd diverse obiecte sau părți ale unor obiecte, de ex. „cadru de piatră al unui cuptor sau coș de fum”, „scobitură în podeaua scenei pentru manevrarea decorurilor".

Pentru adj. clavicular „care aparține claviculei, referitor la claviculă”, DA indică în mod corect ca sursă directă fr. claviculaire, însă DEX adaugă, pe primă poziție, lat. clavicularius, care are cu totul alt sens: „cel care poartă cheile, temnicer" ${ }^{12}$. Derivatul cu sens anatomic de la clavicula este clavicularis, dar, date fiind condițiile istorice în care a pătruns cuvîntul (la jumătatea secolului al XIX-lea, ca termen de anatomie), etimonul francez este suficient.

În unele cazuri, am găsit în altă limbă un etimon înrudit cu cel propus de dicţionarele academice, dar mai apropiat ca sens. Astfel, damă s.f. „scobitură în bordura unei ambarcaţiuni în care se sprijină manșonul vîslei; (învechit) piesă de fontă care închide ușa creuzetului în marile turnătorii” provine din fr. dame, care are exact aceleaşi sensuri ca în română, și nu, cum propune DLR, direct din germ. Damm, care înseamnă „dig, baraj” și care nu corespunde nici din punct de vedere formal (ne-am fi aşteptat la forma ${ }^{*}$ dam). Francezul dame cu sensul din metalurgie are într-adevăr un etimon germanic (conform TLF, franceza a împrumutat inițial olandezul dam cu sensul „dig”, iar sensul din metalurgie reprezintă fie o specializare în interiorul francezei, fie un împrumut independent din germ. Damm). Sensul marinăresc provine fie din cel de „baraj” (piesa împiedicînd căderea vâslei în apă), fie de la dame „femeie” printr-o aluzie erotică (cf. TLF). Un alt exemplu este adjectivul defect, al cărui etimon direct dat de DEX, lat. defectus, este de fapt etimonul îndepărtat; semantic, cuvintul românesc corespunde perfect germanului defekt, în vreme ce lat. defectus, participiul perfect al lui deficere, însemna „lipsit de, deficient, slăbit, sleit”. Dată fiind sfera de aplicare a adjectivului românesc, preponderent tehnică, este de preferat germ. defekt ca etimon direct.

În cazul împrumuturilor cu sursă primară latină, româna prezintă în general aceleași specializări semantice ca limbile moderne. Adesea dicționarele dau etimologii multiple în care figurează și latina, ceea ce se poate justifica prin faptul că cei care au preluat cuvîntul, cunoscîndu-i originea latină, l-au adaptat formal după etimonul latin (spre exemplu, afinitate "potrivire, asemănare; legătură de rudenie” are exact sensul fr.

\footnotetext{
${ }^{12}$ Acesta provine de la sensul primar al lui clavicula, diminutivul lui clavis „cheie”.
} 
affinité, dar din punct de vedere formal corespunde etimonului latin affinitas, care are mai multe sensuri - printre care „rudenie; vecinătate”; ca urmare, originea rom. afinitate poate fi considerată multiplă: din fr. affinité și din lat. affinitas, -atis). Totuși, de la un moment dat încolo, regulile de adaptare a împrumuturilor pe cale scrisă din franceză se fixează, încît nu mai este necesară invocarea etimoanelor latine ca surse directe pentru forma cuvîntului românesc. De aceea, în cazul cuvintelor accelera, atenta, atracție, capabil, DELR a păstrat ca etimon direct doar forma franceză, aşa cum propuseseră DA și CADE, respingînd adăugarea, ca o a doua sursă directă, a etimoanelor latine, care aveau un sens mai larg sau mai concret (accelerare „a grăbi”, attentare „a încerca”, attractio „atragere”, capabilis „care poate cuprinde, primi”). La unele cuvinte, distanța semantică dintre termenul român și cel latin este considerabilă, datorită unei evoluții care a avut loc în interiorul limbii franceze: astfel, pentru agapă și capitula sensurile din română au apărut abia în franceză; lat. agape, termen creștin împrumutat din gr. $\check{\alpha} \gamma \dot{\alpha} \pi \eta$,dragoste (fraternă), afecțiune”, însemna „dragoste creștinească; pomană, masă oferită săracilor; masă luată în comun de către primii creștini, în cursul căreia avea loc împărtăşania”; lat. capitulare însemna „a enumera, a face un raport punct cu punct, a stipula într-un acord, a conveni” (< capitulum „articol, paragraf”). De aceea, adăugarea lat. agape și capitulare la etimoanele franțuzești nu se justifică.

\subsection{Criteriul semantic ca argument împotriva creației interne}

În unele cazuri, criteriul semantic ne-a făcut să respingem derivarea internă, propunînd un etimon străin. Cazul cel mai clar este acela în care sensul asociat presupusului afix derivativ, în română, nu poate explica sensul cuvîntului în discuție. Astfel, DLR consideră verbul tranzitiv demagogiza ca derivat din demagog cu sufixul -iza. Dar, dacă așa ar sta lucrurile, ne-am aștepta ca verbul să însemne „a transforma pe cineva în demagog" - sens dat de DLR pentru infinitivul lung demagogizare, dar care nu se regăsește în exemplele citate. Verbul, rar și învechit, are cu totul alt înțeles, și anume „a încerca să influențeze oamenii printr-o comportare de demagog”, obiectul verbului nefiind o persoană ce devine demagog, ci o persoană influențată în chip demagogic, am spune astăzi „manipulată” (în exemplul din Eminescu citat de DLR, „demagogizarea locuitorilor săteni” nu se referă la transformarea sătenilor în demagogi, ci la influențarea lor în mod demagogic). Acest sens corespunde verbului vechi grec $\delta \eta \mu \alpha \gamma \omega \gamma \varepsilon \tilde{\imath} \nu$, la care, de la sensul general „a conduce poporul”, a apărut firesc, odată cu specializarea peiorativă a bazei $\delta \eta \mu \alpha \gamma \omega \gamma o ́ s$ „conducător al poporului; demagog”, inclusiv sensul „a căuta să influențeze oamenii printr-o comportare de demagog”'13. În consecință, pentru rom. demagogiza am propus fie un împrumut cult din greaca veche, fie intrarea prin intermediul germanei, unde am întîlnit un verb demagogisieren cu acest sens. Un intermediar german este susținut de atestarea cuvîntului la Eminescu. Pe de altă parte, faptul că și în germană verbul demagogisieren este foarte rar ne-a făcut să nu considerăm germana ca sursă sigură.

Alte exemple de acest fel privesc prefixul $d e-$ care, ca element productiv în română, are doar un sens pe care l-am putea numi „privativ”: „a scoate dintr-o stare, a îndepărta, a efectua o transformare opusă celei exprimate de verbul-bază". DLR tratează ca derivate în română, cu de-, unele cuvinte unde $d e-$ nu are această contribuție semantică. Este vorba, de fapt, de împrumuturi: spre exemplu, vb. delucida (învechit) „a explica” provine din it. delucidare și lat. delucidare, derivat tîrziu din lucidus „luminos; clar, limpede” pe modelul lui dilucidare, elucidare, în niciun caz nu este derivat intern din de- + elucida, așa cum propune DLR; la fel, vb. depreda (rar, învechit) „a prăda; (despre plante) a distruge” este un împrumut din lat. depredari (< predari „a prăda” < preda „pradă”) (DLR scrie aici „Cf. prăda”); adj. degenerator „care face să degenereze; degenerativ" nu poate proveni din generator, cum susține DLR, ci este un împrumut din fr. dégénérateur, cuvînt rar, dar atestat în secolul XIX cu sensul "degenerativ” (derivat de la dégénérer „a degenera”) ${ }^{14}$. În ceea ce privește vb. derîde ( $\left.r a r\right)$ „a-și bate joc de cineva”, DLR propune tot derivarea din de- și rîde, deși este vorba de refacerea unui verb regresiv pe baza substantivului abstract derîdere. Acesta din urmă este mult mai folosit și are un etimon extern, provenind, cu românizare (după rîde) și echivalarea

\footnotetext{
${ }^{13}$ Un component semantic cu sensul „a conduce” este prezent chiar în forma cuvîntului grec: $\delta \eta \mu \alpha \gamma \omega \gamma o ́ s<\delta \tilde{\eta} \mu \circ \varsigma$ "popor"

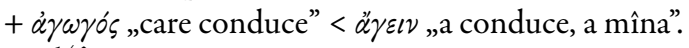

${ }^{14}$ Împrumutul din franceză este susținut de data la care apare cuvintul (1862, Pontbriant, D.).
} 
sufixului, din fr. dérision „deriziune, bătaie de joc” ${ }^{15}$ (astfel, la origine era un dublet cu românizare al lui deriziune), care la rîndul lui este un împrumut din lat. derisio, abstractul lui deridere „a lua în rîs”. Așadar, derivarea cu $d e-s$-a produs, în acest caz, tocmai în latină, la sursa îndepărtată a cuvîntului românesc.

Am întîlnit și situații în care baza propusă nu are sensul potrivit: pentru digitalic adj. și subst. „(medicament) bazat pe digitalină”, DLR indică ca etimon digital, însă cele două adjective digital înregistrate de DLR, „referitor la degete” și „(informatică) care este sau poate fi reprezentat prin cifre” nu corespund din punctul de vedere al sensului; există o altă bază internă posibilă, digitală „numele a două plante erbacee veninoase din familia scrofulariaceelor; substanță extrasă din frunzele digitalei, numită în general digitalină”, care este potrivită din punct de vedere semantic, însă, datorită caracterului tehnic al cuvîntului, am optat pentru fr. digitalique.

În cele mai multe cazuri în care am respins formarea internă, criteriul semantic s-a combinat cu cel istoric: este vorba de situații în care caracterul specializat, tehnic al unui cuvînt pledează pentru un împrumut, dat fiind că disciplinele respective, cu vocabularul tehnic aferent, s-au dezvoltat mai întîi în alte țări, fiind preluate de români prin contact cultural. Astfel, pentru africanologie s.f. este mai probabil fr. africanologie decît derivarea din Africa susținută de DEX; cheiaj s.n. „staționare la chei a unei nave; taxă pentru a putea încărca sau descărca marfa la chei” provine din fr. quayage, cum indică SDLR, și nu din chei $+-a j$ (soluția DEX); pentru termenul de geometrie conciclic adj. „(despre puncte) care se află pe același cerc" este de reținut etimonul fr. concyclique propus de $\mathrm{CADE}$, și nu derivarea internă con- + ciclic dată de DEX; pentru combinor s.n. „organ suplimentar al fiecărui selector dintr-o centrală telefonică automată, folosit pentru a produce schimbări succesive în constituția circuitelor” am optat pentru fr. combineur, respingînd derivarea din combina indicată de D EX; curant, adjectiv folosit în expresia medic curant, este cel mai probabil împrumutat din it. curante, nu derivat din cura „a îngriji un bolnav”, cum propune DEX. Alte exemple de acest fel sint: cristalinitate s.f. (termen de geologie) „grad de cristalizare a unei roci eruptive” (DELR: din fr. cristalinité, germ. Kristalinität; DEX: din cristalin), cristalizator s.n. „vas de laborator sau aparat industrial folosit pentru cristalizarea substanțelor dintr-o soluție” (DELR: din fr. cristallisateur; DEX: din cristaliza), decarbonizație s.f. (învechit, cu referire la sînge) „eliminarea dioxidului de carbon” (DELR: germ. Dekarbonisation, fr. décarbonisation; DLR: din de-și carbonizație) și o serie de compuse: cerebrastenie s.f. „formă de astenie a creierului” (DN³ , DELR: fr. cérébrasthénie; DEX: din cerebr[al] și astenie), exocortex s.n. (termen de botanică) „strat extern al regiunii corticale” (DELR: engl. exocortex, fr. exocortex; DLR: din exo- + cortex), fotocrom adj. „care îşi schimbă culoarea sub acțiunea luminii” (DELR: fr. photochrome; DEX: regresiv din fotocromie), fotocromatic adj. „fotocrom” (DELR: fr. photochromatique, engl. photochromatic; DEX: din fotocrom + -atic, o derivare inutilă, atîta timp cît cele două adjective sînt sinonime, improbabilă și fiindcă sufixul moștenit -atic nu se atașează bazelor neologice; în acest caz, grupul -at- provine din etimon, gr. $\chi \rho \tilde{\omega} \mu \alpha, \chi \rho \omega \dot{\mu} \mu \alpha \tau o \zeta$, ,culoare”), paraclinic adj. (despre o examinare medicală) „cu mijloace suplimentare faţă de cea făcută prin observarea directă a bolnavului” (DELR: fr. paraclinique; DEX: din para- + clinic), pedoclimatic adj. „referitor la microclimatul solului” (DELR: fr. pédoclimatique, engl. pedoclimatic; DEX: din pedo- + climatic), pluricarpelar adj. (termen de botanică) „format din mai multe carpele” (DN ${ }^{3}$, DELR: fr. pluricarpellaire; DLR: pluri- + carpelă +ar), policromat adj. „executat din materiale de diverse culori” (DELR: fr. polychromé; DEX: din policrom), portclișeu s.n. „casetă de lemn sau de metal în care se introducea clișeul fotografic” (DELR: fr. porte-cliché, adaptat după clişseu; DEX: din port- ${ }^{1}+$ clișeu), pseudococaină s.f. „ester obținut, ca și cocaina, din frunzele de coca, întrebuințat ca anestezic local" (DELR: fr. pseudococaïne, engl. pseudococaine; DLR, DEX: din pseudo-+ cocaină), tetracarbonil s. (DELR: fr. tétracarbonyle (de nickel), engl. (nickel) tetracarbonyl; DLR: din tetra- și carbonil), topoclimatologie s.f. „ramură a climatologiei care studiază influența condițiilor topografice asupra climatului" (DELR: fr. topoclimatologie, posibil și engl. topoclimatology; DEX: din topo+ climatologie).

${ }^{15}$ Astfel explicate, derîdere și deriziune reprezintă un dublet sinonimic format dintr-un împrumut și un calc structural care, în cazul de față, îmbracă forma românizării, vezi Stanciu-Istrate (2006, p. 147, 299), Moroianu (2016, p. 265). 


\subsection{Criteriul semantic ca argument pentru creația internă}

Deși mult mai rare, nu lipsesc situațiile în care diferența de sens față de presupusa limbă-sursă ne-a făcut să adoptăm soluția formării interne (eventual influențată formal de limba respectivă). Astfel, cuplă s.f. „dispozitiv demontabil pentru legarea a două vehicule (mai ales feroviare) sau a două elemente aparținînd unui sistem tehnic" nu poate proveni din fr. couple, cum susţine DEX, deoarece couple nu este atestat cu acest sens tehnic, ci doar cu sensul „cuplu, pereche” (forma feminină este o variantă mai veche a masculinului couple „cuplu”). Așadar, am adoptat soluția derivării regresive din verbul cupla. Adjectivul precaut nu corespunde semantic etimonului lat. precautus indicat de DLR și DEX, care avea un sens pasiv „de care s-a avut grijă”. Ca atare, l-am considerat derivat regresiv din precauţie. Pentru calcio-vecchio „gen de tencuială ornamentală”, forma sugerează o origine italiană, astfel nu este de mirare că DEX l-a considerat cuvînt italian. În italiană nu am putut repera, însă, o sintagmă calcio vecchio cu acest sens; Treccani notează trei cuvinte calcio: calcio ${ }^{1}$ "călcîi” (< lat. calx); calcio ${ }^{2}$ „lovitură cu piciorul; fotbal; lovitură la jocul de biliard" (< calciare ,a lovi cu piciorul” < calcio ${ }^{1}$ ), calcio ${ }^{3}$ "calciu” (împrumut din lat. savant Calcium, derivat din calx „var”). Nu dispunem de suficiente informații despre istoria acestui gen de tencuială și a denumirii sale care să permită o soluție sigură, de aceea soluția propusă în DELR are calificativul „probabil”. În absența unei surse externe dovedite, am presupus că este vorba de un fals italienism creat în română, unde it. calcio (masculin) a fost folosit, în mod eronat, pentru femininul calce ,var”, determinînd acordul la masculin al adjectivului vecchio „vechi”.

\section{Criteriul cronologic}

În privința neologismelor, o problemă frecventă este existența mai multor surse posibile. Stabilirea datei la care a pătruns cuvintul în română este una din metodele care permit să se ia o decizie între aceste surse posibile. Dispunînd de o bază documentară mai amplă, cuprinzînd numeroase texte vechi transcrise în format electronic, în care este posibilă căutarea cuvintelor, am fost în măsură să aducem o serie de corijări, găsind atestări care sînt fie prea vechi, fie prea noi pentru etimonul propus în dicționarele noastre academice. Astfel, adjectivul și substantivul calvin „creștin-protestant adept al doctrinei lui Calvin”, apărînd încă de la 1600, într-un document din Transilvania (Doc. Î. XXXII) și avînd și alte atestări în limba veche (la Varlaam, la Miron Costin, la Dosoftei, la Axinte Uricariul, în Îns. ms. etc.), nu poate proveni din franceză, cum susține DA, ci este împrumutat din lat. calvinus, care era folosit și ca substantiv comun, și ca adjectiv. Pentru crenel, atestat încă de la 1839 (Negruzzi, O. II, 172), etimonul corect este cel dat de DA, CADE, CDER 2557, și anume fr. créneau, cu refacerea formei etimologice a sufixului -eau (v.fr. crenel), sprijinită și de derivatele fr. créneler, crénelé. DEX, datorită formei, propune engl. crenel, ceea ce însă este neverosimil pentru prima jumătate a secolului al XIX-lea. Sînt și cazuri unde cronologia indică o fază ulterioară influenței franceze: verbul clica ,a selecta, pe un computer, o fereastră, un simbol etc., apăsînd mouse-ul cînd cursorul se află în dreptul elementului respectiv", pătruns în limbă odată cu calculatoarele personale și interfețele grafice ce folosesc mouse-ul, este evident raportabil la engl. click fie ca derivat din substantivul românesc $c l i c$ (< engl. click), cf. expresiile a face clic, a da clic, fie ca împrumut din verbul englez to click. Etimologia franceză (cliquer) propusă de DEX este, în contextul dat, mai mult decît improbabilă.

Criteriul cronologic se referă și la circulația cuvîntului în presupusa limbă-sursă. Astfel, la substantivul xerocopie, atestat la 1966 ( $\mathrm{LTR}^{2}$ ), pentru etimoanele propuse de DLR (fr. xérocopie, it. xerocopia) nu am putut găsi atestări mai vechi de 1966. Atestări mai vechi sînt însă disponibile pentru engl. xerocopy (de ex., în revista „Photographic Engineering”, 6-7, 1955, p. 257, 258). În consecință, am propus o etimologie engleză (termenul s-a format probabil în engleză, pe baza lui xerography „xerografie” < xero- < gr. छ̆pós „uscat” + -graphy și copy „copie”).

În multe cazuri, criteriul cronologic a dus la respingerea etimologiei interne în favoarea unui împrumut. Astfel, DLR tratează verbul excontentelui (învechit, folosit în Transilvania) „a acorda o despăgubire” ca provenit din verbul excontenta, cu același sens (pentru a cărui etimologie se indică „cf. esconta”). În forma, de asemenea învechită, escontentelui, cuvintul este atestat la 1806 (Iorga, S. D. XII), înaintea lui 
excontenta, pentru care prima atestare disponibilă este la 1844 (Barițiu, C. IV, 196). De fapt, este vorba de variante de adaptare a verbului latin excontentare, între cele două forme neexistînd vreun raport de derivare. La fel stau lucrurile cu adjectivele învechite danic și danicesc „danez”, considerate în DLR ca derivate din

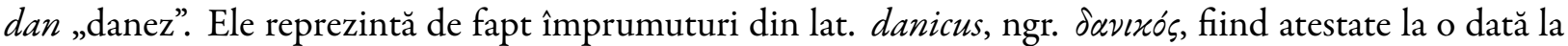
care sufixul -ic-abia intra în limbă, adesea adaptat în forma -icesc: danicesc este atestat la 1829 (AR, 95), iar danic la 1842 (Asachi, L. 16). Adaptarea sufixului latino-romanic-icus (-ico,-ique) în forma-icesc caracterizează limba veche şi este anterioară adoptării sufixului în forma -ic.

Cuvintele demofil și demofilie sînt atestate aproximativ în aceeași perioadă: demofil în 1936 (Crainic, P. card. 48), demofilie în 1935 (Diamandi, O. P. 188). De aceea, nu este justificată propunerea DLR de a1 considera pe al doilea derivat din primul (care doar el ar avea un etimon extern, fr. démophile). Mai probabil, întreaga familie a fost împrumutată din franceză (démophile, démophilie).

Criteriul cronologic, combinat cu cel al istoriei conceptului/referentului, indică o sursă externă pentru o serie de derivate de la nume de locuri pe care alte dicționare academice le consideră creații interne. Astfel, dacă toponimul-bază este un loc nefamiliar românilor în perioada respectivă, iar sufixul nu era productiv în limbă la acea dată, este de presupus că derivatul reprezintă un împrumut. Astfel, african, adj. (și subst.) atestat încă din sec. XVII (1682, Dosoftei, V. S., octombrie, $\left.87^{r}\right)^{16}$ nu poate fi format în română de la

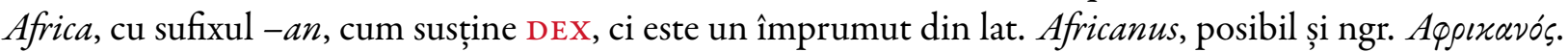
Adj. (și s.m.) chinez nu poate fi format în română de la China, cum susţine DEX, deoarece este atestat la 1830 (Iancu Văcărescu, poezia „Tipografia”), la vremea cînd sufixul $-e z$ cu siguranță nu era productiv în limbă, ci abia pătrundea prin împrumuturi. Etnonimul a fost împrumutat din limbile occidentale (it. Cinese, germ. Chinese, fr. Chinois), iar inițiala a fost modificată după China. Adjectivul chinezesc, atestat mai devreme, la 1802 (Amorven și Zalida, romanțchinezesc, tradus probabil de Alecu Beldiman, din franceză, citat de Ursu \& Ursu, 2011), conține elementul -ez-, care nu se poate explica prin derivare internă; el reprezintă o adaptare a germ. chinesisch, it. cinese, cu sufixul -esc ca marcă a clasei adjectivelor de apartenență (vezi și cazul lui -icesc). La fel, pentru caucazian, adj. (și subst.) atestat la 1848 (Brezoianu, Î. 113) este de presupus împrumutul din fr. caucasien, în locul derivării de la toponimul Caucaz, indicată de DEX.

Un caz asemănător îl reprezintă derivatul deantroponimic chirilic, pentru care DA și DEX indică drept etimon numele propriu Chiril. Cuvîntul apare încă de la începutul secolului al XIX-lea, fiind atestat la Petru Maior, în forma cirilic, în Dialogu pentru începutul limbei română, publicat în 1819. În același text mai apar și formele cirilicesc și chirilicesc. Cum la această epocă sufixul -ic abia pătrundea în limbă, prin împrumuturi, este cert că acest adjectiv nu este o formație internă, ci un împrumut din lat. cyrillicus. Tot Petru Maior folosise într-un text anterior (publicat în 1812), Dissertațiepentru începutul limbei românești, adjectivul cirilian, tot un împrumut, de această dată din lat. cyrillianus. Mai întîlnim în prima jumătate a secolului al XIX-lea forma țirilicesc (într-o traducere a unui text latin al lui Petru Maior, din 1834, v. Maior, S. II, 209), explicabilă atît prin lat. cyrillicus, cît și prin germ. cyrillisch. Pronunția cu chi- o urmează, evident, pe cea a numelui propriu Chiril.

O situaţie specială în care cronologia atestărilor este de ajutor o reprezintă termenii tehnici ce desemnează activități, care sînt realizați lingvistic atît prin verbe, cît și prin nume abstracte. Deși, din punct de vedere formal și sincronic, numele se prezintă, în general, ca derivat de la verb, din punct de vedere istoric uneori lucrurile stau invers: termenul pătrunde întîi ca substantiv abstract, în care sufixul abstract din limba-sursă este echivalat cu $-r e^{17}$; ulterior, se creează și verbul corespunzător, prin derivare regresivă. Iată cîteva exemple la care atestările disponibile indică un asemenea traseu, infirmînd derivarea numelui în română de la verb, susținută de DEX: climatizare s.f. este atestat încă din 1949 (LTR R ${ }^{1}$, I) și este folosit mult mai frecvent decît corespondentul verbal climatiza, atestat abia în 1978 ( $\left.\mathrm{DN}^{3}\right)$, ceea ce ne-a condus

\footnotetext{
${ }^{16}$ Puțin înainte, în Let. cantac. (1665-1672), cuvîntul apare ca parte a unui nume propriu, Sțipio African.

${ }^{17}$ Vezi, pentru numeroase alte exemple, Carabulea \& Popescu-Marin (1967, p. 277-320). Bogdan-Oprea (2011, p. 9697) discută acest aspect în contextul „relatinizării limbii române”. Pentru conceptul de „echivalare sufixală” în comparație cu substituția și cu calcul lingvistic, vezi Moroianu (2017, p. 335-347).
} 
spre explicarea lui climatizare ca adaptare a fr. climatisation, cu echivalarea sufixului; cobaltare s.f. este și el atestat în 1949 ( $\mathrm{LTR}^{1}$, I), iar cobalta abia în $1978\left(\mathrm{DN}^{3}\right)$, fapt care confirmă luarea în considerare de către noi a etimonului fr. cobaltage (propus și de $\mathrm{DN}^{3}$ ) și a germ. Kobaltierung, cu echivalarea sufixului; colectivizare s.f. este atestat în 1948 (Contemp. nr. 109, 4/2), înainte de verbul colectiviza (atestat în 1953, Cursul scurt de istorie a PCUS, citat în DLRLC) și folosit mult mai frecvent decît acesta, inclusiv în sintagme de tipul colectivizare forțată, colectivizarea agriculturii, proces de colectivizare etc., ceea ce indică justețea împrumutului din rus. kollektivizacija, cu echivalarea sufixului.

\section{Criteriul frecvenței în limba-sursă}

În cazul termenilor tehnici din vocabularele diferitelor discipline științifice, este adesea greu de reperat limba-sursă și este foarte probabilă existența mai multor limbi-sursă. Astfel, pe lîngă franceză, trebuie avute în vedere germana, engleza și, pentru o anumită perioadă, rusa. Dicționarele academice recente (DEX şi DLR) dau prioritate francezei, cu excepția împrumuturilor foarte recente, unde începe să fie admisă și engleza. Această prioritate este desigur justificată de realitățile istorice (franceza fiind limba de circulație internaţională cel mai bine cunoscută în țara noastră pînă spre sfîrşitul sec. al XX-lea), însă în unele cazuri a fost dusă prea departe. Unele etimoane franceze propuse de dicționarele academice recente sînt fie extrem de rare, fie nu au putut fi deloc atestate. În elaborarea DELR, procedăm astfel: după verificarea etimonului în dicționarele de referință ale francezei (TLF, Robert, Larousse), verificăm existența termenului în surse disponibile online-diverse dicționare tehnice, Wikipedia, pagini scrise în franceză-acordînd prioritate căutării în cărți ${ }^{18}$ și alegînd o anumită perioadă de căutare, pentru a verifica existența termenului în lucrări ce preced prima atestare a cuvîntului în română. Aceeași procedură este aplicată și altor posibile limbisursă.

Începem discuția cu o serie de situații în care etimonul propus de DEX sau DLR nu a putut fi atestat deloc (este vorba de presupuse cuvinte franceze, cu o singură excepție, v. mai jos crib). Distingem următoarele sub-tipuri:

(i) Cuvîntul provine de fapt din altă limbă: calcocloroză s.f. „fenomen de îngălbenire a frunzelor unei plante din cauza lipsei de fier asimilabil din sol” $<$ calco- + cloroză, după germ. Kalkchlorose (DEX: fr. chalcochlorose); chemitipie s.f. „tehnică a gravării clișeelor fotografice pe cale chimică” < germ. Chemitypie (DEX: fr. chémotypie); citocromie s.f. „procedeu rapid de tipar în patru culori suprapuse, la care forma parțială de negru servește la realizarea efectelor de tonuri închise” < germ. Citochromie,

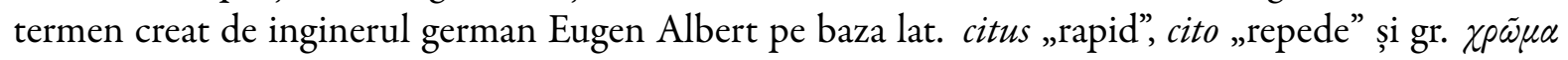
„culoare, ten, nuanţă (DEX: fr. cytochromie); climostat s.n. „instrument cu care se măsoară efectul termic al factorilor climatici asupra clădirilor” < germ. Klimostat, rus. klimostat (DEX: fr. climostat); crib s.n. „construcție plasată în albia unui rîu pentru a proteja sorbul unei pompe care se alimentează din apa respectivă” < engl. [water] crib, propriu-zis ,iesle, loc îngrădit, mic șopron” (DEX: germ. Kri$b b e$; de fapt, acesta este un cuvînt olandez și dialectal nord-german, al cărui corespondent în germana literară este Krippe); cromoalgrafie s.f. „algrafie folosită pentru forme de tipar multicolore” < germ. Chromoalgraphie (DEX: fr. chromoalgraphie); delint s.n. "material fibros obținut din lintersul extras de pe suprafața semințelor de bumbac, întrebuințat la fabricarea hîrtiei fine, a nitrocelulozei și a mătăsii artificiale” < engl. delint < delint vb. „a scoate lintersul” $<$ de $-(<$ lat. de-) + lint "puf (de in, de bumbac etc.)" < lat. linteum „pînză de in” (< linum ,in”) sau v.fr. linette „sămînță de in” < lin „in” < lat. linum „in” (DLR: fr. délint);

(ii) Cuvîntul a fost de fapt creat în română: canisă s.f. „crescătorie de ciini”, probabil creat de la baza can(i) - din canin, canid (DEX: fr. canice); celaperm s.n. „fibră obținută pe cale chimică din celuloza de bumbac, cu aceleași proprietăți ca celofibra, dar cu un tușeu deosebit”, probabil format din cel(a) $(<$ celuloză $)+-$ perm $(<$ permeabil) (DEX: fr. celaperm); celofibră s.f. „fibră textilă artificială obținută

\footnotetext{
${ }^{18}$ Pentru aceasta folosim opțiunea respectivă a motorului de căutare Google.
} 
din celuloză” < celo- $(\leftarrow$ celuloză $)+$ fibră (DEX: fr. cellofibre); carpatin adj. < Carpați (soluție dată deja de DA și CADE; DEX: fr. karpathin);

(iii) Cuvîntul are de fapt o altă formă decît cea indicată: corona s.f. „tip de descărcare electrică de forma unei coroane; formațiune anatomică cu aspect de coroană” < fr. (effet) corona, engl. corona (DEX propune fr. coronne, cuvint inexistent, și germ. Krone, care însă nu are sensul „tip de descărcare electrică de forma unei coroane”, pentru care se folosește expresia Koronaentladung „descărcare-corona”); decozină s.f. „alcaloid extras din nemțișor (Delphinium consolida), care ajută la scăderea tensiunii arteriale și la încetinirea ritmului cardiac" < fr., engl. delcosine, termen format, probabil, pe baza numelui științific al plantei (DLR: fr. décozine).

Prezentăm acum o serie de cazuri în care un etimon a fost respins deoarece s-a dovedit a fi extrem de rar în presupusa limbă-sursă:

(i) Cuvîntul provine de fapt din altă limbă: astroclimat s.n. „totalitatea condițiilor climatice relevante pentru efectuarea de observații astronomice" < engl. astroclimate, rus. astroklimat (DEX: fr. astroclimat); caracterograf s.n. „aparat electronic care permite vizualizarea caracteristicilor dispozitivelor semiconductoare pe ecranul unui tub catodic" 1988 < rus. charakterograf (DEX indică engl. characterographe (sic!); o formă characteograph apare într-adevăr în engleză, dar este extrem de rară); catometru s.n. „aparat folosit pentru controlul mărimilor caracteristice ale tuburilor electronice” < germ. Kathometer, engl. cathometer < cathode "catod” + -meter (DEX: fr. catomètre); cenotip s.n. „organism care conține structura caracteristică grupului din care face parte” < engl. coenotype < coen< gr. roıvós „comun” + type (DEX: fr. cénotype). În cazul substantivului cvartet, etimonul it. quartetto indicat de DA, CADE, SDLR, CDER și DEX este acceptabil, însă DEX adaugă și fr. quartette, ceea ce nu este verosimil dat fiind caracterul lui foarte rar în franceză (termenul obișnuit pentru cvartet este quatuor). Este probabil însă că românescul cvartet are, pe lîngă italiană, și o sursă germană - Quartett.

(ii) Cuvîntul a fost de fapt creat în română: dedentiție s.f. (termen medical) „pierdere a dinților”, probabil derivat de la dentiție, cu de- privativ (fr. dédentition indicat de DEX și DLR este foarte rar; cuvintele obişnuite cu sens privativ de la dent- au în fr. prefixul é-: édenter etc.); dendrometrist s.m. „specialist în dendrometrie", derivat din dendrometrie, cu substituirea sufixului (DEX, DLR: fr. dendrométriste); hidrocosmetică s.f. „ramură a cosmeticii care folosește cu predilecție apa și preparatele cosmetice hidratante", format probabil în română din hidro- + cosmetică (fr. hydrocosmétique propus de DEX se întîlnește extrem de rar, ca adjectiv, scris hydro-cosmetique).

(iii) Cuvintul reprezintă un calc structural: bioamplificator s.n. (med.) „aparat electronic folosit pentru amplificarea biopotenţialelor musculare", atestat la 1988 (DEX-S), este format din bio- + amplificator, după engl. bioamplifier. DEX propune fr. bioamplificateur, însă acesta este un cuvînt rar, neatestat anterior cuvîntului românesc.

În unele situații, circulația presupusului etimon în limba-sursă este limitată la o perioadă sau o regiune în care această limbă nu a fost în contact cu româna. Astfel, pentru advent, pe lîngă lat. adventus, indicat de DEX, și germ. Advent, indicat de MDN, ambele de acceptat, DEX adaugă și fr. advent. Însă aceasta este o formă învechită, dispărută după sec. al XVII-lea, forma curentă fiind Avent. Pentru adaptor s.n., DEX indică fr. adapteur, însă acesta este un anglicism folosit mai ales în Canada. Cuvîntul provine de fapt din engl. adaptor/adapter. Contractor adj. și s.m. „(persoană) care contractează; persoană care oferă servicii, pe baza unui contract”, atestat încă de la 1813 (Doc. Orh., 463), provine probabil, într-o primă perioadă, din germ. Kontraktor și rus. kontraktor, iar în zilele noastre a fost întărit sau reintrodus prin engl. contractor. Etimonul indicat de DEX, fr. contracteur, nu este acceptabil, deoarece este vorba de un anglicism recent în franceză. Verbul învechit defensa „a ocroti, a apăra”, atestat la 1848 (Negulici, V.), se explică prin dorința de a crea în română o familie de la baza lat. defendere (în aceeași perioadă pătrund defenda, defende, defensă, defensie, defensibil); în acest caz s-a recurs la lat. defensare, frecventativul lui defendere, probabil deoarece oferea o formă mai apropiată de cea a abstractului defensă, care intrase din franceză. DEX propune, pentru defensa, un verb francez défenser, însă acesta ieșise din uz în secolul al 
XIX-lea (potrivit TLF, acest verb este limitat la franceza medie).

\section{Criteriul istoriei conceptului / referentului}

În privința neologismelor, acest criteriu este folosit în special în cazul etimologiei îndepărtate, fiind implicat în identificarea limbii în care termenul respectiv apare pentru prima dată. Există însă și situații în care s-a dovedit relevant pentru etimologia directă—singura prezentată, prin tradiție, în celelalte dicționare academice actuale.

Astfel, am întîlnit două exemple de compuse savante formate în română pentru care dicționarele academice, bazîndu-se pe situația obișnuită a termenilor tehnici neologici, au propus etimoane străine:

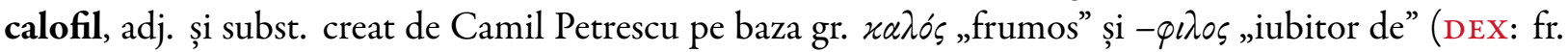
callophile); vulcanocarst s.n. "carst format pe roci eruptive”, termen creat de geologul român T. Naum pentru a desemna un fenomen geologic specific Munților Căliman (DLR: rus. vulkanokarst).

În cazul substantivului crotálie „mică plăcuță metalică aplicată pe urechea animalelor ca semn de

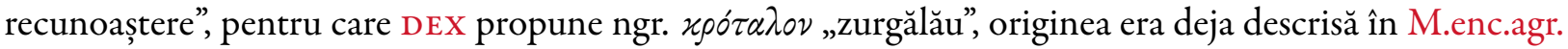
(vol. III, 698): este vorba de un termen comercial, Crotalia, introdus de firma germană Hauptner în 1887, pe baza lat. crotalia ( $p l$. tantum) „cercei cu mai multe perle, care, lovindu-se unele de altele, scot un sunet ca de crotal” (< crotalum „crotal, instrument muzical de percuție, compus din două plăcuțe legate între

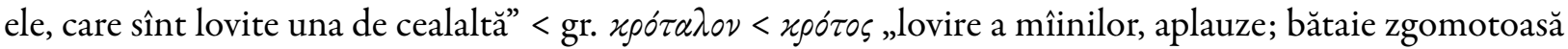
din picioare; lovire răsunătoare a unui obiect”).

Pentru deculator s.n. „aparat folosit în industria hîrtiei pentru îndepărtarea aerului din pasta de hîrtie”, DLR propune fr. découleur, pe care nu am reușit să-l găsim folosit cu acest sens (are puține ocurențe, pe cîteva site-uri, în alte contexte; nu este atestat în niciun dicționar). Deculator provine de fapt din engl. deculator, denumire comercială introdusă de firma Clark \& Vicario Corp., formată de la numele inventatorului aparatului, inginerul chimist american Judson Albert De Cew.

În cazul mărcilor comerciale, este de presupus că denumirea produsului a intrat în limbă odată cu importarea produsului propriu-zis, fiind inscripționată pe produse sau pe ambalaje. De aceea, în cazul unui cuvînt precum corhart s.n. „material aluminos refractar, folosit la căptușirea cuptoarelor pentru fabricarea sticlei", produs al concernului industrial englez Corhart Refractories (format în anii '20 ai secolului trecut prin asocierea companiilor Corning Glass Works și Hartford Empire ${ }^{19}$ ), pare mai plauzibil ca inginerii români să fi preluat direct denumirea comercială englezească decît să fi preluat cuvîntul din texte scrise în vreo limbă intermediară. Astfel, este de respins soluția propusă de DEX, anume fr. corharte (de observat și că forma sub care cuvintul a circulat în franceză este corhart, o formă cu - $e$ final nu este atestată).

\section{Cuvinte pentru care nu a mai fost propus niciun etimon}

Există şi cîteva neologisme pentru care nu s-a propus nicio etimologie în dicționarele academice recente și în cele de neologisme (fiind marcate cu „et. nec.” în DEX și DLR). Dintre acestea, am clarificat etimologia următoarelor cuvinte:

(i) caprotină s.f. „gen fosil de moluște bivalve cretacice, cu cochilia groasă și cu valve inegal dezvoltate”: fr., engl. Caprotina, nume dat de naturalistul francez Alcide d'Orbigny în 1842, după genul înrudit Caprina;

(ii) chenaf s.m. „plantă erbacee cu flori galbene, utilizată în producerea fibrelor textile (Hibiscus cannabinus)": fr. kénaf < pers. kenaf;

(iii) ciumiză s.f. „plantă graminee furajeră cu frunze late și cu inflorescența în formă de panicul (Setaria italica-maxima)": rus. čumiza (< chinez choumizi, potrivit ESUM);

\footnotetext{
${ }^{19}$ Numele Corhart s-a format prin contopirea segmentelor iniţiale ale numelor celor două companii.
} 
Ion Giurgea, Cristian Moroianu \& Monica Vasileanu

(iv) coleí vb. „a îndepărta părul de pe pieile unor animale, prin aplicarea unor substanțe depilatoare”: probabil fr. coller ,a lipi” (așadar un dublet al verbului cola), explicabil prin faptul că pasta folosită în acest procedeu se lipește de piele;

(v) cupíu s.n. (rar) „unitate (bancnotă, hîrtie de valoare) în care se împarte o sumă de bani”, cuvînt atestat în DOOM ${ }^{1}$ și preluat de DEX; este vorba, de fapt, de un singular refăcut din pluralul cupiuri (cu mutare a accentului, cupiuri < cupiúri) al variantei cupiúră a substantivului cupúră, cu același sens, pentru care pronunțarea recomandată este /ku'pyrə/ (cf. DEX, care nu face legătura între cele două cuvinte); acesta este un împrumut din fr. coupure, propriu-zis „tăietură”. Etimologia lui cupiu a fost descoperită de colega noastră Mihaela Morcov, redactor al DELR.

(vi) daourit (pronunțat daurit; ieșit din uz) „rubelit”: fr. daourite, nume dat de mineralogul francez Leclerc de Buffon, pe baza top. Daourie, regiune în sudul Siberiei, de unde fusese adus un eșantion de rubelit;

(vii) decelit „material plastic asemănător cu linoleumul, folosit în poligrafie datorită proprietății de a primi şi de a ceda ușor cerneala de imprimare”: germ. Decelith, denumire comercială.

\section{Concluzii}

Cercetarea etimologică de astăzi dispune, fără îndoială, de incontestabile avantaje față de etapele anterioare, în primul rînd datorită corpusurilor electronice de texte care permit o cercetare mai amănunţită a momentului, modului și contextului în care s-a format prin mijloace interne, a fost împrumutat sau a fost modelat după una sau mai multe surse externe un anumit cuvint. Posibilitatea de a avea la dispoziție atît dicționare și lucrări științifice de ultimă generație, cît și texte (literare sau neliterare) ne oferă, pe de o parte, posibilitatea de a gîndi și reconstitui în cunoștință de cauză etimologia cuvintelor (de la cele vechi și populare pînă la cele moderne și chiar recente) și ne responsabilizează, pe de altă parte, să aducem cercetarea etimologică românească la standardele actuale. Academia Română reprezintă etalonul cercetării în toate domeniile culturii, iar dicționarele scoase sub egida sa trebuie să se caracterizeze printr-un maximum de rigoare și de corectitudine științifică. Dorința de a amenda dicționarele anterioare are deja tradiție în lexicologia românească ${ }^{20}$ și trebuie să ducă la firești corijări și completări fie că ele sînt ale noastre, fie că sînt ale altora, mai ales atunci cînd este vorba despre lucrări colective realizate sub același patronaj instituțional. Fără o corelare a rezultatelor cercetărilor diverselor colective de redactori, dicţionarele noastre academice vor continua să perpetueze unele etimologii discutabile, iar eforturile de aducere la zi a materialului lexicografic românesc nu vor avea rezultatul dorit, acela de armonizare a contribuțiilor științifice academice în domeniul lexicologiei și, în mod particular, al etimologiei. În acest sens, redactorii DELR lucrează la realizarea unei versiuni actualizate a primelor două volume deja publicate, care să corespundă structurii celui de al treilea, acțiune care presupune, în mod inevitabil, corectări, completări și reevaluări lexicologice (legate de sensuri, atestări, surse, variante și etimologii). Astfel, într-o versiune electronică pe cale de a se realiza odată cu refacerea literei A, vom fi în măsură să ameliorăm în permanență informațiile, în funcție de ceea ce descoperim pe parcurs. În acest sens, contribuțiile etimologice ale confraților de la institutele de lingvistică din țară ale Academiei Române (Institutul de Lingvistică și Istorie Literară „Sextil Pușcariu” din Cluj-Napoca și Institutul de Filologie Română „Alexandru Philippide” din Iași) ne sînt și ne vor fi în continuare de mare ajutor.

\section{Bibliografie}

\section{A. Dictionare}

CADE = Candrea, I.-A. \& Adamescu, Gh. (1931). Dicționarul enciclopedic ilustrat, Editura Cartea Românească, București.

\footnotetext{
${ }^{20}$ Dintre promotorii unor asemenea reacții este de citat, alături de Al. Graur, în primul rînd Theodor Hristea prin cel puțin trei lucrări de referință (Hristea, 1960, p. 235-257; 2007, p. 23-38; 2009, p. 481-498), la care putem adăuga contribuțiile importante ale lui Andrei Avram (1997,2001, 2006), Dumitru Loșonți (2001, 2007) sau ale Iuliei Mărgărit (2005, 2010).
} 
CDDE = Candrea, I.-A. \& Densusianu, Ov. (1907-1914). Dicționarul etimologic al limbii române. Elementele latine (A-Putea), Socec, București.

CDER = Ciorănescu, Al. (2002). Dicționarul etimologic al limbii române, ediție îngrijită și traducere din limba spaniolă de T. Șandru-Mehedinți și M. Popescu Marin, Editura Saeculum I. O., București.

D.med. = P. Simici (red. responsabil), Dicționar medical, Editura Medicală, București, 2 vol.

DA = Academia Română, Dicționarul limbii române. Sub conducerea lui Sextil Pușcariu. Tomul I. Partea I: $A-B$, Librăriile Socec \& Co. și C. Sfetea, București, 1913; Tomul I. Partea II: C, Tipografia Ziarului „Universul”, București, 1940; Tomul I. Partea III. Fascicula I: $D-d e$, „Universul”, Intreprindere Industrială a Statului, București, 1949; [Fascicula II: De-desțina; șpalt, 1948]; Tomul II. Partea I: F-I, Monitorul Oficial și Imprimeriile Statului. Imprimeria Națională, București, 1934; Tomul II. Partea II. Fascicula I: J-lacustru, Tipografia Ziarului „Universul” S.A., București, 1937; Tomul II. Partea II. Fascicula II: Ladă-lepăda, Tipografia Ziarului „Universul” S.A., București, 1940; Tomul II. Partea II. Fascicula III: Lepăda-lojniță, Tipografia Ziarului „Universul” S.A., București, 1948.

$\mathrm{DCR}^{3}=$ Dimitrescu, F., Ciolan, Al. \& Lupu, C. (2013). Dicționar de cuvinte recente, ediția a III-a, Editura Logos, București. DELR = Dicționarul etimologic al limbii române, coordonat de A. Avram \& M. Sala (vol. I, II I $_{1}$, I. Giurgea \& C. Moroianu (vol. $\mathrm{II}_{2}$ ), Editura Academiei Române, București, vol. I, $A-B$, 2011; vol. II, partea I, Ca-cizmă, 2015; vol. II, partea II, Clac-cyborg, 2018.

DEX = Coteanu, I. \& Mareș, L. (coord.), Dicționarul explicativ al limbii române. Ediția a II-a, Editura Univers Enciclopedic, București, 1996; reeditat cu adăugiri în 1998, 2009, 2012, 2016.

DîlL = Chivu, Gh., Buză, E. \& Roman Moraru, A. (1992). Dicționarul împrumuturilor latino-romanice în limba română veche (1421-1760), Editura Științifică, București, 1992.

DLR = Academia Română, Dicţionarul limbii române. Serie nouă. Redactori responsabili: acad. Iorgu Iordan, acad. Alexandru Graur şi acad. Ion Coteanu. Din anul 2000, redactori responsabili: acad. Marius Sala și acad. Gheorghe Mihăilă. București, Editura Academiei. Tomul I. Partea a 3-a. Litera D (D-Deînmulţit), 2006; Tomul I. Partea a 4-a. Litera D (Deja-Deținere), 2006; Tomul I. Partea a 5-a. Litera D (Deținut-Discopotiriu), 2007; Tomul I. Partea a 6-a. Litera D (Discord-Dyke), 2009; Tomul I. Partea a 7-a. Litera E (E-Erzaț), 2009; Tomul I. Partea a 8-a. Litera E (Es-Ezredeș), 2010; Tomul III. Literele J, K, Q, 2010; Tomul IV. Litera L (L-Lherzolită), 2008; Tomul V. Litera L (Li-Luzulă), 2008; Tomul VI. Litera M, 1965-1968; Tomul VII. Partea 1. Litera N, 1971; Tomul VII. Partea a 2-a. Litera $O$, 1969; Tomul VIII. Partea 1. Litera $P(P-P a ̆ z u i)$, 1972; Tomul VIII. Partea a 2-a. Litera P (Pe-Pînar), 1974; Tomul VIII. Partea a 3-a. Litera P (Pînă-Pogribanie), 1977; Tomul VIII. Partea a 4-a. Litera P (Pogrijanie-Presimțire), 1980; Tomul VIII. Partea a 5-a. Litera P (Presin-Puzzolană), 1984; Tomul IX. Litera R, 1975; Tomul X. Partea 1. Litera $S$ (S-Sclabuc), 1986; Tomul X. Partea a 2-a. Litera $S$ (ScladăSemînţărie), 1987; Tomul X. Partea a 3-a. Litera S (Semn-Sîveică), 1990; Tomul X. Partea a 4-a. Litera S (Slab-Sponghios), 1992; Tomul X. Partea a 5-a. Litera $S$ (Spongiar-Swing), 1994; Tomul XI. Partea 1. Litera S, 1978; Tomul XI. Partea a 2-a. Litera T (T-Tocăliță), 1982; Tomul XI. Partea a 3-a. Litera $T$ (Tocăna-Twist), 1983; Tomul XII. Partea I. Litera T, 1994; Tomul XII. Partea a 2-a. Litera $U$, 2002; Tomul XIII. Partea 1. Litera $V(V$-Veni), 1997; Tomul XIII. Partea a 2-a. Litera $V$ (Venial-Vizurină), 2002; Tomul XIII. Partea a 3-a. Litera $V$ (Vîclă-Vuzum) și Literele $W, X, Y$, 2005; Tomul XIV. Litera $Z, 2000$.

DLRLC = Dicționarul limbii române literare contemporane (sub direcția prof. univ. Dimitrie Macrea și acad. Emil Petrovici).

Volumul I: $A-C$, 1955; volumul al II-lea: $D-L, 1956$; volumul al III-lea: $M-R$, 1957; volumul al IV-lea: $S-Z, 1958$,

Editura Academiei, [București].

$\mathrm{DN}^{2}$ = Marcu, F. \& Maneca, C. (1966). Dicționar de neologisme, ediția a II-a, Editura Științifică, București.

$\mathrm{DN}^{3}=$ Marcu, F. \& Maneca, C. (1978). Dicționar de neologisme, ediția a III-a, Editura Academiei, București.

DoOM $^{1}=$ Avram, M. (red. responsabil) (1982). Dicționarul ortografic, ortoepic și morfologic al limbii române, Editura Academiei

R.S.R, București.

ESUM = Mel'ničuk, O.S. (coord.) (1982-2012). Etimologičnyj slovnyk ukrainskoi movy, Nauk, Dumka, Kiev.

Larousse $=$ Dictionnaire de français $[$ online $]$.

LTR $^{1}$ = Lexiconul tehnic român. Bucureşti, Editura Tehnică; vol. I, 1949; vol. II, 1950; vol. III, 1951; vol. IV, 1952; vol. V, 1954, vol. VI-VII, 1955.

$\mathrm{LTR}^{2}=$ Lexiconul tehnic român. Elaborare nouă. Întocmită prin îngrijirea A.S.I.T. de un colectiv sub conducerea prof. Remus

Răduleț. Bucureşti, Editura Tehnică; vol. I-II, 1957; vol. III-IV, 1958; vol. V, 1959; vol. VI-VII, 1960; vol. VIII-IX, 1961;

vol.X-XI 1962; vol. XII-XIII, 1963; vol. XIV-XV, 1964; vol. XVI-XVII, 1965; vol. XVIII, 1966; vol. XIX „Indice”, 1968. MDA = Micul dicționar academic, Editura Univers Enciclopedic, București. Volumul I: $A-C$, 2001; volumul al II-lea: $D-H$, 2002; volumul al III-lea: I-Pr, 2003; volumul al IV-lea: $\operatorname{Pr}-Z, 2003$.

MDN = Marcu, F. (2000). Marele dicționar de neologisme. Ediție revizuită, augmentată și actualizată, Editura Saeculum, București.

M.enc.agr. = Filipescu, C. (coord.), Marea enciclopedie agricolă, Editura P.A.S., București. Vol. I, 1937; II, 1938; III, 1940; IV, 1942; V, 1943.

NDU = Oprea, I., Pamfil, C.-G., Radu, R. \& Zăstroiu, V. (2006). Noul dicționar universal al limbii române, Litera Internațional,

București / Chișinău, 2006.

PEW = Pușcariu, S. (1905). Etymologisches Wörterbuch der rumänischen Sprache, I: Lateinisches Element, mit Berücksichtigung 
aller romanischen Sprachen, K. Winter, Heidelberg.

Robert = Robert, P. (1996). Le Grand Robert de la Langue Française. Dictionnaire alphabétique et analogique de la langue française. $2^{\mathrm{e}}$ édition entièrement revue et enrichie par Alain Rey, Le Robert, Paris, 9 vol.

SDLR = Scriban, A. (1939). Dicționaru limbii românești. (Etimologii, înțelesuri, exemple, citaţiuni, arhaizme, neologizme, provincializme), Edițiunea întîia, Institutul de Arte Grafice „Presa Bună”, Iași.

TDRG $^{2}=$ Tiktin, H., Rumänisch-deutsches Wörterbuch, 2., überarbeitete und ergänzte Auflage von Paul Miron, Otto Harrassowitz, Wiesbaden. Band I, 1986; Band II, 1988; Band III, 1989.

$\mathrm{TDRG}^{3}=$ Tiktin, H., Rumänisch-deutsches Wörterbuch, 3., überarbeitete und ergänzte Auflage von Paul Miron und Elsa Lüder, Clusium, Cluj-Napoca. Band I, 2000; Band II, 2003; Band III, 2005.

TLF = Trésor de la Langue Française. Dictionnaire de la langue du XIX et du XX eiècle (1789-1960). Paris, 1972 ș.u. [online].

Treccani = Dizionario della lingua italiana, pubblicato dall'Istituto dell'Enciclopedia Italiana fondata da Giovanni Treccani e Giunti T.V.P. editori, Firenze, 2014 [online].

\section{B. Lucrări de referință}

Avram, A. (1997). Contribuții etimologice, Univers Enciclopedic, București.

Avram, A. (2001). Noi contribuții etimologice, Univers Enciclopedic, București.

Avram, A. (2006). Comentarii și ipoteze etimologice, Editura Academiei Române, București.

Bogdan-Oprea, H. (2011). Relatinizarea limbii române: privire generală, accepțiii, delimitări, aspecte, Editura Universității din București, București.

Carabulea, E. \& Popescu-Marin, M. (1967). Exprimarea numelui de acțiune prin substantive cu formă de infinitiv lung și de supin, în „Studii și materiale privitoare la formarea cuvintelor în limba română”, vol. IV, red. resp.: acad. Al. Graur şi M. Avram, Editura Academiei, București, p. 277-320.

Hristea, Th. (1960). Probleme de etimologie în „Dicționarul limbii române moderne”, în „Studii și cercetări lingvistice”, 9 (2), p. 235-257.

Hristea, Th. (1968). Probleme de etimologie: studii, articole, note, Editura Științifică, București.

Hristea, Th. (1973a). Contribuții la studiul etimologic al neologismelor românești, în „Limba română”, 22 (1), p. 3-15.

Hristea, Th. (1973b). Criterii de diferențiere a formațiilor interne de imprumuturi, în „Analele Universității din București. Limba și literatura română", 22 (1), p. 143-155.

Hristea, Th. (2007). Etimologia în principalele lucrări lexicografice românești. Considerații critice, în Pană Dindelegan, G. \& Stoica, G. (coord.), „Limba română. Stadiul actual al cercetării. Actele celui de al 6-lea Colocviu al Catedrei de limba română (29-30 noiembrie 2006)", Editura Universității din București, București, p. 23-38.

Hristea, Th. (2009). Considerații pe marginea unui dicționar etimologic: CDER, în „Limba română”, 58 (4), p. 481-498.

Keppel Hesselink, J.M. (2015). The terms 'autacoid', 'hormone' and 'chalone' and how they have shifted with time, în "Autonomic and Autocoid Pharmacology", 35 (4), p. 51-58, Crossref.

Loșonți, D. (2001). Soluții și sugestii etimologice, Univers Enciclopedic, București.

Loșonți, D. (2007). Certitudini și ipoteze etimologice, Editura Academiei Române, București.

Mărgărit, I. (2005). Ipoteze și sugestii etimologice. Note și articole, Editura Academiei Române, București.

Mărgărit, I. (2010). Noi comentarii etimologice și semantice, Editura Academiei Române, București.

Moroianu, C. (2008). Derivarea prin substituție de afixe. Sufixe neologice, în Bejan, D. M., Lucatelli, V. \& Cenac, O. (coord.), „Lexic comun / Lexic specializat. Actele Conferinței internaționale Lexic comun / Lexic specializat, Galați, 17-18 septembrie, 2008”, „Analele Universității Dunărea de Jos din Galați”, Fascicula XXIV, An 1, Nr. 1, Galați University Press, p. 194-206.

Moroianu, C. (2009). Derivarea prin substituție de afixe. Sufixe substantivale vechi, în Saramandu, N., Nevaci, M. \& Radu, C.I. (eds), „Lucrările celui de-al doilea Simpozion Internațional de Lingvistică (București, 28-29 noiembrie, 2008)”, Editura Universității din București, București, p. 281-294.

Moroianu, C. (2016). Motivarea formală a relațiilor semantice. Sinonimia analizabilă, Editura Universității din București, București.

Moroianu, C. (2017). Adaptarea imprumuturilor prin echivalare sufixală, în Stanciu Istrate, M. \& Răuțu, D. (eds), „Lucrările Celui de-al 6-a Simpozion internațional de lingvistică (București, 29-30 mai 2015)”, Editura Univers Enciclopedic Gold, București, p. 335-347.

Sala, M. (1999). Introducere în etimologia limbii române, Editura Univers Enciclopedic, București.

Seche, L. (1960). Cuvinte și sensuri noi în presa actuală, în „Limba Română”, 9 (1), p. 57-65.

Stanciu-Istrate, M. (2006). Calcul lingvistic în limba română (cu specială referire la scrieri beletristice din sec. XIX), Editura Academiei Române, București.

Ursu, N.A. \& Ursu, D. (2011). Imprumutul lexical în procesul modernizării limbii române literare (1760-1860), Editura Cronica, Iași, vol. III, Repertoriu de cuvinte și forme - supliment, 2 părți. 